\title{
An Unusual Ventriculoperitoneal Shunt Complication: Spontaneous Knot Formation
}

\author{
Straduşı Bir Ventriküloperitoneal Şant Komplikasyonu: \\ Spontan Düğ̈̈m Oluşumu
}

\author{
Alp Ozgun BORCEK, Soner CIVI, Mustafa GOLEN, Hakan EMMEZ, M. Kemali BAYKANER \\ Gazi University, Faculty of Medicine, Department of Neurosurgery, Ankara, Turkey \\ Presented at: 23rd Scientific Congress of Turkish Neurosurgical Society, April 2009, Kyrenia, Turkish Republic of Northern Cyprus
}

Correspondence address: Alp Ozgun BORCEK / E-mail: alpob@yahoo.com

\begin{abstract}
This article aims to describe an extraordinary complication of a ventriculoperitoneal shunt system that formed a knot spontaneously and lead to a shunt malfunction. A 3-year-old male patient was operated due to posttraumatic hydrocephalus. After an uneventful follow-up period of 34 months, he presented with shunt malfunction. During the shunt revision surgery, the peritoneal catheter was found to form a loop over itself. There are various complications of ventriculoperitoneal shunt systems. Migration to body cavities is among the most interesting ones. This is the fifth report describing this rare complication. Hydrocephalic patients should be closely followed up after shunt surgery for various extraordinary complications.
\end{abstract}

KEYWORDS: V/P Shunt, Shunt Complication, Shunt Malfunction

öz

Bu makale, kendi üzerine katlanarak bir düğüm oluşturup şant malfonksiyonuna neden olan ventriküloperitoneal şant sisteminin yol açtığı bu sıradışı bir komplikasyonu incelemektedir. Travma sonrasında gelişen hidrosefali nedeni ile opere edilen 3 yaşındaki erkek hasta 34 aylık sorunsuz bir takip süresi ardından şant malfonksiyonu ile başvurdu. Şant revizyonu sırasında peritoneal kateterin kendi üzerine katlanarak bir düğüm oluşturduğu gözlendi. Ventriküloperitoneal şant sistemlerine ait birçok farklı komplikasyon bildirilmiştir. Vücut boşluklarına migrasyon bu komplikasyonlardan en ilginç olanlar arasındadır. Bu makalede, sunulan vaka literatürdeki beşinci vakadır. Hidrosefalili hastalar şant cerrahisi sonrasında bu komplikasyonlar için yakın takipte tutulmalıdırlar.

ANAHTAR SÖZCÜKLER:V/P Şant, Şant komplikasyonları, Şant malfonksiyonu

\section{INTRODUCTION}

Ventriculoperitoneal (V/P) shunts are commonly useful surgical materials used for treatment of cerebrospinal fluid circulation disorders. Although the procedure is used frequently in general neurosurgical practice and regarded as a safe intervention, it has several usual and unusual complications. Shunt infection, fracture and malfunctioning due to obstructive debris are among the usual complications. On the other hand, there are various examples of unusual complications such as migration of the shunt hardware through body cavities. This paper describes a shunt that presented with obstruction due to spontaneous formation of a loop over itself.

\section{CASE REPORT}

A 3-year-old male patient was admitted to our intensive care unit after a closed head injury. His Glasgow Coma Score was 13 (E3V4M6). His radiological investigation revealed a left frontal lobe contusion and bilateral subdural collection that did not require surgical intervention (Figure 1). He recovered gradually during 10 days of uneventful follow up period and discharged normally.

Two months after his discharge, he was admitted to the emergency room with drowsiness and excessive vomiting. He had bilateral $6^{\text {th }}$ nerve palsy in his neurological examination. Due to his previous history, hydrocephalus was suspected and his emergent CT confirmed the diagnosis (Figure 2). He underwent $\mathrm{V} / \mathrm{P}$ shunting operation and his symptoms quickly resolved after the procedure and he was discharged on the $7^{\text {th }}$ day of the operation. His postoperative shunt series were normal (Figure 3).

After an uneventful follow-up period of 34 months, he was admitted to another clinic due to headache and up-gaze palsy continuing for the last 10 days. His neurological examination was normal except the $6^{\text {th }}$ nerve palsy. There was evident hydrocephalus on his magnetic resonance imaging (MRI) and was referred to our department for further evaluation (Figure 4). Shunt malfunction was supposed and his shunt 
series were taken. Shunt series revealed collection of the peritoneal part of the shunt system under the right diaphragm (Figure 5A,B).

He underwent shunt revision surgery. During the abdominal exploration, the peritoneal catheter was found forming a loop over itself, like a knot (Figure 6). After untangling, we discovered that there was no cerebrospinal fluid flow through the catheter. The whole shunt system was revised. He was discharged after full recovery.

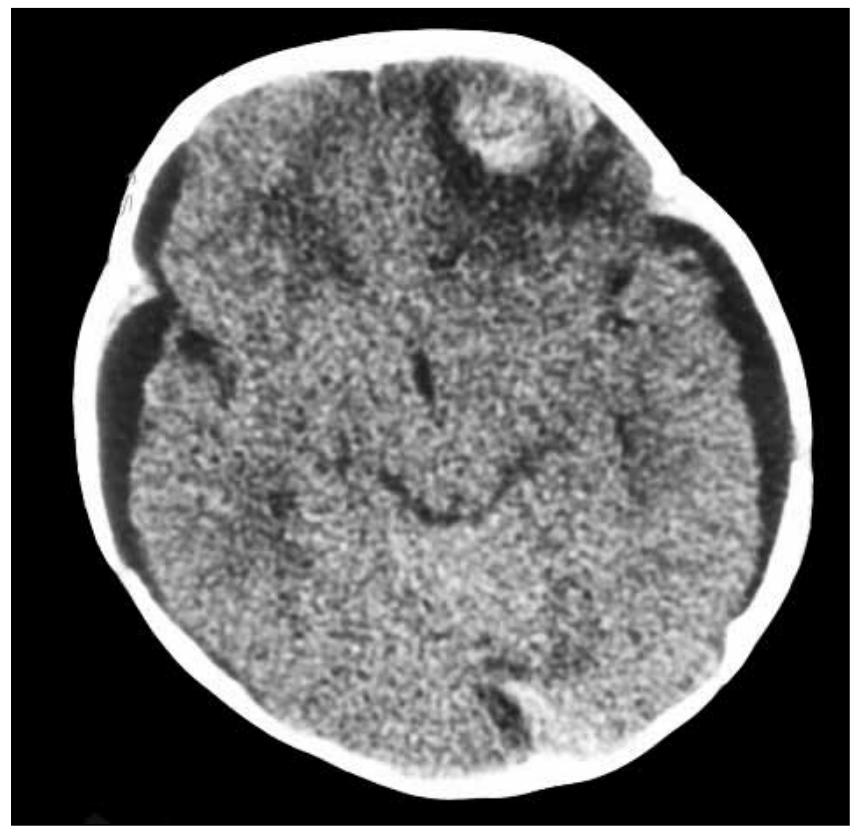

Figure 1: Cranial CT demonstrating left frontal lobe contusion and bilateral subdural collection after the trauma.

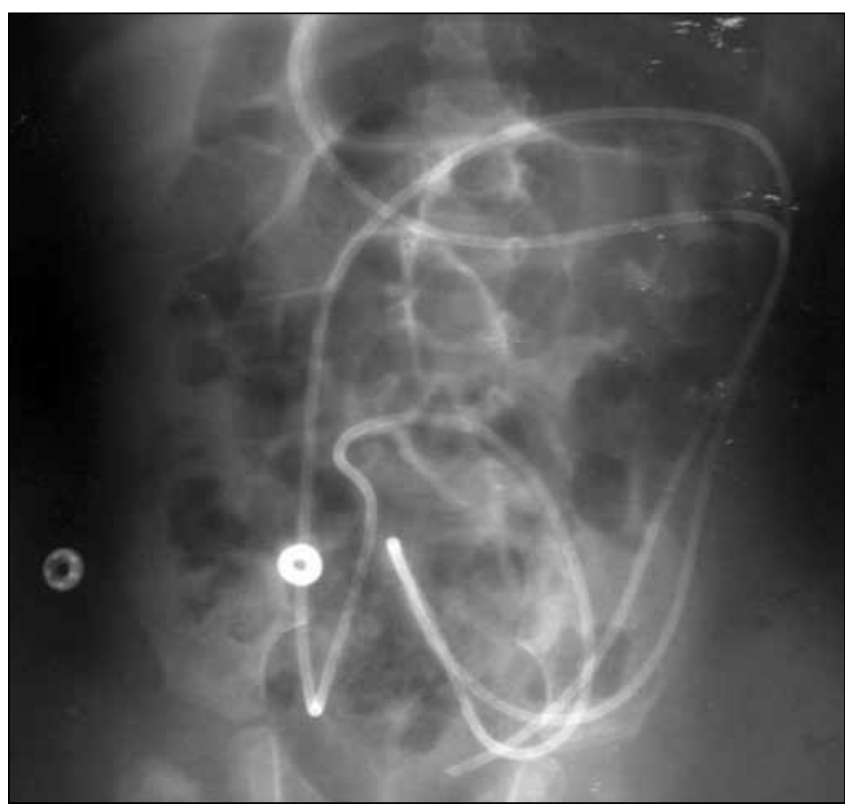

Figure 3: Shunt series demonstrating well-spread peritoneal catheter after the first operation.

\section{DISCUSSION}

Cerebrospinal fluid shunting devices are complication prone systems. The complication rates significantly differ between different procedures. The common sites for distal tubing includes the atrial, plevral, ureteral and peritoneal shunting, where ventriculoatrial shunting with the highest complication rates (79\% in a series by Murtagh et al) (13). On the other hand the complication rates of ventriculoperitoneal systems are estimated as $47 \%$. And about half of these complications involve the distal end of the tubing system.

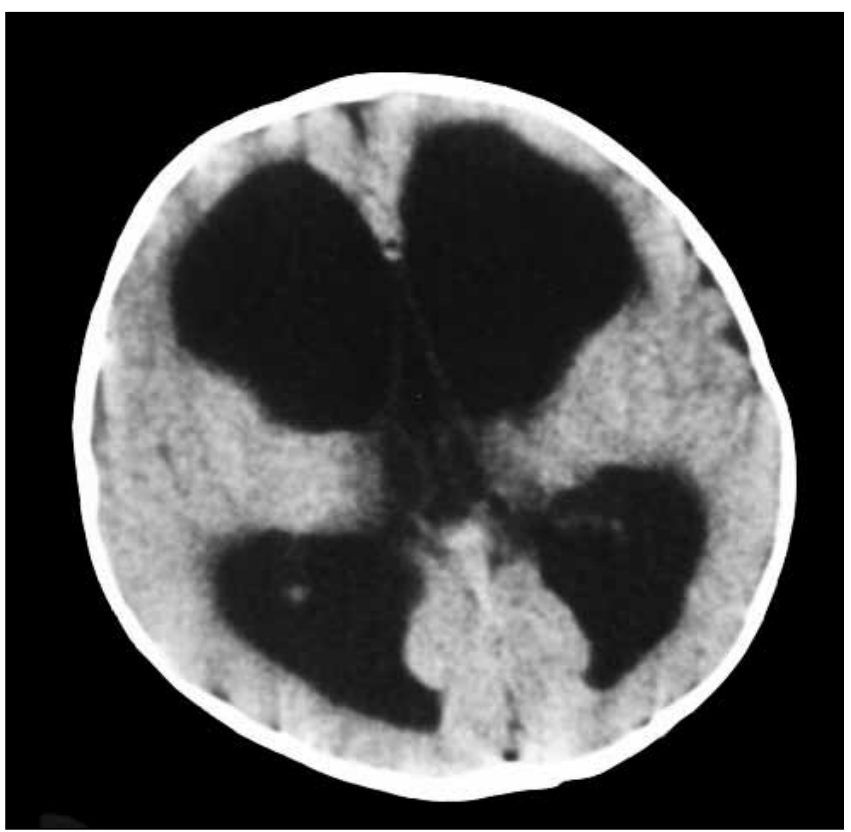

Figure 2: Cranial CT demonstrating hydrocephalus two months after the trauma.

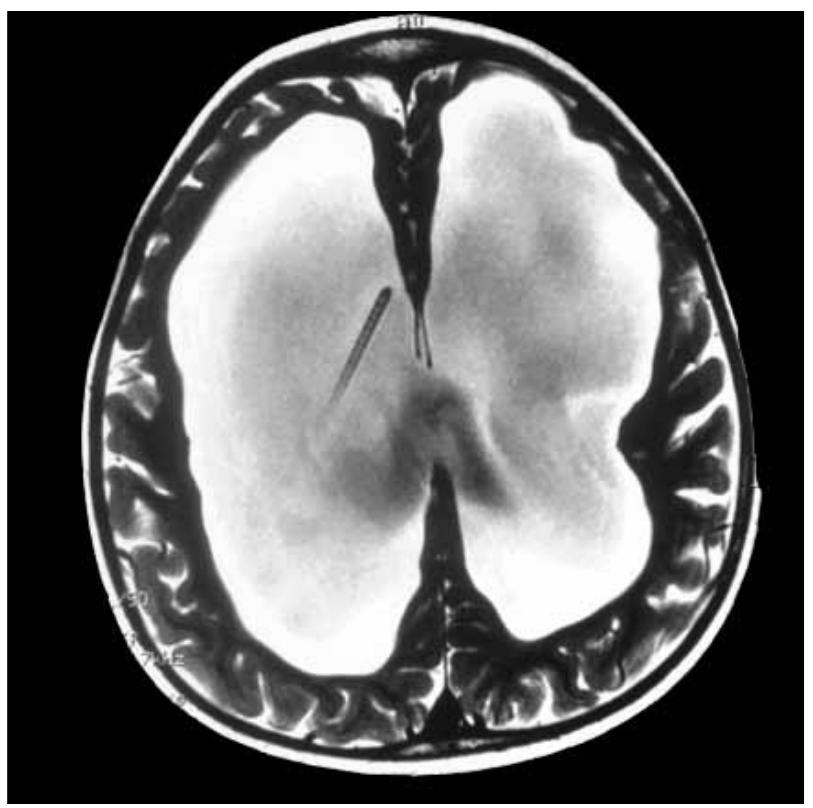

Figure 4: Cranial MRI demonstrating recurrent hydrocephalus and ventricular catheter in place. 

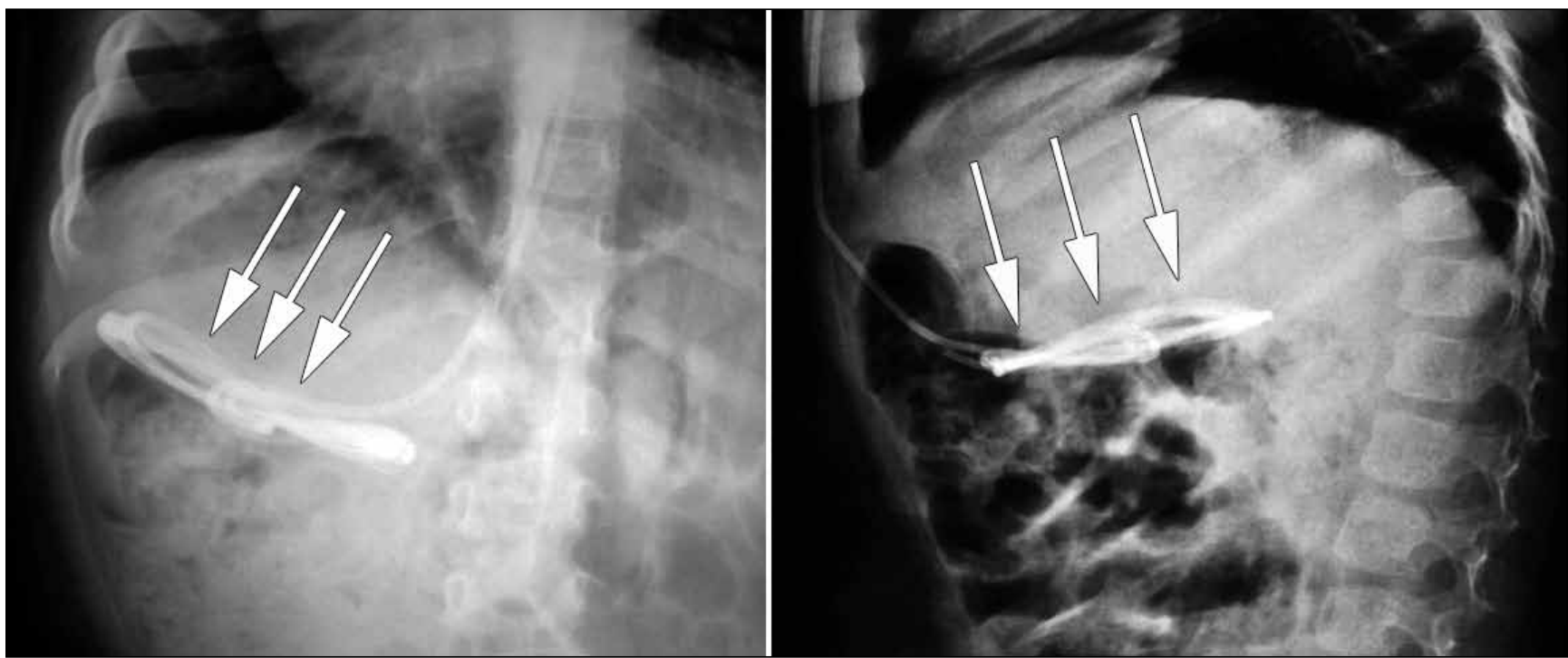

Figure 5: Shunt series taken before the second operation demonstrating the collection of the peritoneal catheter under the right diaphragm (Arrows: peritoneal catheter).

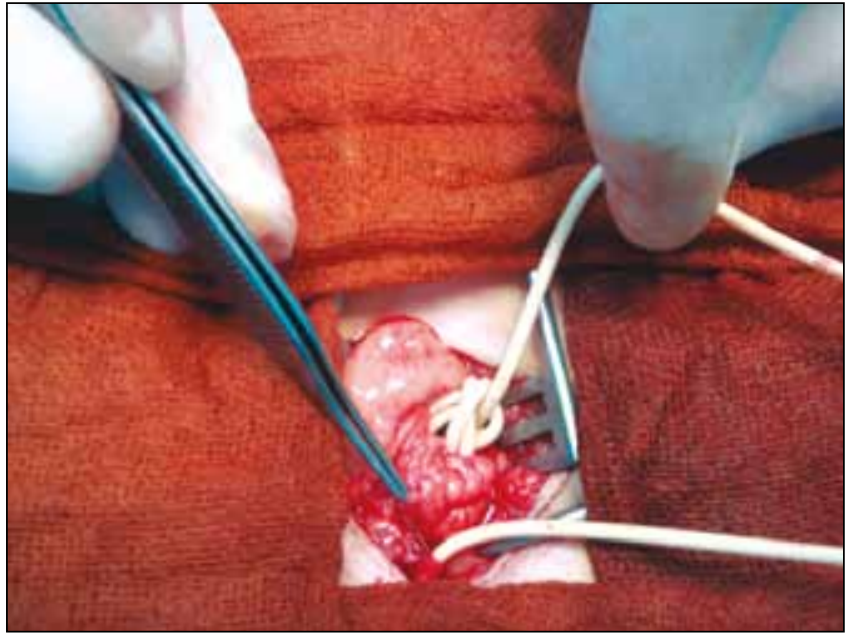

Figure 6: Intraoperative photograph demonstrating the loop forming a knot at the peritoneal catheter.

The complications of ventriculoperitoneal shunt include obstruction of the hardware $(15,3 \%)$, infection $(8,2 \%)$, seizure $(7,1 \%)$ and other complications related to the shunt device $(6,1 \%)(12)$. Infections, obstruction and fractures are the usual indications of shunt revisions. There are various interesting complications due to shunts in the literature. Among these, migration to the body compartments is common. Shunts migrated to the mediastinum $(1,6)$, heart $(4,9)$, abdominal wall $(8,17)$ and scrotum $(2,11)$ have been reported. Besides these, interesting examples of oral (3) and rectal $(10,14,16)$ protrusions of the distal catheter have also been reported.

A literature search revealed five similar cases. The first was reported by Murtagh et al in 1980 and was describing an occasion where the shunt tubing was found to be knotted tightly around the bowel (13). The second was reported in 1998 by Starreveled et al and was describing a 1-week- old female infant suffering from intestinal obstruction due to knotting of peritoneal catheter (15). The third case was described by Chopra et al in 2004 (5). Their patient was a 25-year-old pregnant woman. The authors suggested the growing uterus as a facilitating factor in catheter looping. The fourth case was reported by Woerdeman et al in 2006 and was describing an infant who required a V/P shunting due to lumbosacral meningomyelocele (18). They accuse the peristalsis as an underlying factor. Finally, in 2008, Eftekhar et al have reported a 3.5-year-old boy who presented with intestinal obstruction and intraabdominal cyst formation due to peritoneal catheter knotting (7).

We do not know the underlying mechanism of this complication. Intestinal peristalsis may be responsible. Additionally, surgical technique during the first operation may be accused; however, we think that, postoperative shunt series and 34 months of uneventful follow up period after the first operation refutes this possibility.

\section{CONCLUSION}

Patients with V/P shunts may present with awkward complications as well as the usual ones. Close follow up of these patients with serial CT and shunt series is mandatory.

\section{REFERENCES}

1. Akyuz M, Ucar T, Goksu E: A thoracic complication of ventriculoperitoneal shunt: Symptomatic hydrothorax from intrathoracic migration of a ventriculoperitoneal shunt catheter. British Journal of Neurosurgery 18:171-173, 2004

2. Ammar A, Ibrahim AW, Nasser M, Rashid M: CSF hydroceleunusual complication of V-P shunt. Neurosurgical Review 14:141-143, 1991

3. Berhouma M, Messerer M, Houissa S, Khaldi M: Transoral protrusion of a peritoneal catheter: A rare complication of ventriculoperitoneal shunt. Pediatric Neurosurgery 44: 169-171, 2008 
4. Chong JY, Kim JM, Cho DC, Kim CH: Upward migration of distal ventriculoperitoneal shunt catheter into the heart: Case report. J Korean Neurosurg Soc 44:170-173, 2008

5. Chopra I, Gnanalingham K, Pal D, Peterson D: A knot in the catheter - an unusual cause of ventriculo-peritoneal shunt blockage. Acta Neurochirurgica 146:1055-1057, 2004

6. Doh JW, Bae HG, Lee KS, Yun IG, Byun BJ: Hydrothorax from intrathoracic migration of a ventriculoperitoneal shunt catheter. Surgical Neurology 43:340-343, 1995

7. Eftekhar B, Hunn A: Ventriculoperitoneal shunt blockage due to spontaneous knot formation in the peritoneal catheter. Case report. J Neurosurg Pediatr 1:142-143, 2008

8. Eser O, Dogru O, Aslan A, Kundak AA: Umbilical perforation: An unusual complication of a ventriculoperitoneal shunt. Childs Nervous System 22:1509-1510, 2006

9. Fewel ME, Garton HJ: Migration of distal ventriculoperitoneal shunt catheter into the heart. Case report and review of the literature. Journal of Neurosurgery 100:206-211, 2004

10. Jindal A, Kansal S, Mahapatra AK: Unusual complication-VP shunt coming out per rectum and brain abscess. Indian Journal of Pediatrics 66:463-465, 1999

11. Karaosmanoğlu D, Metin Y, Akata D, Haliloğlu M: An unusual cause of hydrocele: Malpositioned ventriculoperitoneal shunt in the scrotum. Journal of Ultrasound in Medicine 27:159-160, 2008
12. Kim HK, Seo EK, Cho YJ, Kim SJ: Hydrothorax due to migration of ventriculoperitoneal shunt catheter. J Korean Neurosurg Soc 43:159-161, 2008

13. Murtagh F, Quencer R, Poole C: Extracranial complications of cerebrospinal fluid shunt function in childhood hydrocephalus. American Journal of Roentgenology 135: 763-766, 1980

14. O'Donoghue GT, Kumar R, Taleb F, Phillips J: Per-anal extrusion of a disconnected ventriculoperitoneal catheter--an unusual complication. Irish Medical Journal 95:88-89, 2002

15. Starreveld Y, Poenaru D, Ellis P: Ventriculoperitoneal shunt knot: A rare cause of bowel obstruction and ischemia. Canadian Journal of Surgery 41:239-240, 1998

16. Sturdee SW, Timothy J, Tyagi A: Total extrusion of a cranial peritoneal shunt per rectum. J Clin Neurosci 9:199-200, 2002

17. Wani AA, Ramzan A, Wani MA: Protrusion of a peritoneal catheter through the umblicus: An unusual complication of a ventriculoperitoneal shunt. Pediatric Surgery International 18:171-172, 2002

18. Woerdeman PA, Hanlo PW: Ventriculoperitoneal shunt occlusion due to spontaneous intraabdominal knot formation in the catheter. Journal of Neurosurgery: Pediatrics 105:231232,2006 